\title{
Silk Road Apples-Collection, Evaluation, and Utilization of Malus sieversii from Central Asia
}

\author{
James Luby ${ }^{1}$ \\ University of Minnesota, Department of Horticultural Science, St. Paul, MN 55108 \\ Philip Forsline \\ United States Department of Agriculture, Agricultural Research Service, Plant Genetic Resources Unit, Cornell \\ University, Geneva, NY 14456-0462 \\ Herb Aldwinckle \\ Department of Plant Pathology, Cornell University, Geneva, NY 14456-0462 \\ Vincent Bus \\ The Horticulture and Food Research Institute of New Zealand, Ltd., Hawkes Bay Research Centre, Private Bag \\ 1401, Havelock North, New Zealand \\ Martin Geibel \\ Genebank for Fruit, Dresden - Pillnitz, Bergweg 23, D-01326 Dresden, Germany
}

\begin{abstract}
Malus sieversii Lebed., a wild apple species native to Central Asia, is recognized as a major progenitor of the domesticated apple, $M$. $\times$ domestica Borkh. (Juniper et al., 1999; Morgan and Richards, 1993; Ponomarenko, 1987, 1992; Way et al., 1992). In ancient times, apple seeds and trees were probably dispersed from Central Asia east to
\end{abstract}

\footnotetext{
Received for publication 22 May 2000. Accepted for publication 13 June 2000. We gratefully acknowledge the contributions and expertise of all the cooperators who provided information on their germplasm evaluation and utilization activities (Table 1). The collection expeditions could not have been successful without the gracious cooperation of Prof. Aimak Djangaliev and his staff of the Republic of Kazakhstan Academy of Sciences and the efforts of Drs. Allan Stoner and Calvin Sperling of the USDA/ARS National Germplasm Resources Laboratory in Beltsville, Md., who provided critical research leadership and essential funding. The cost of publishing this paper was defrayed in part by the payment of page charges. Under postal regulations, this paper therefore must be hereby marked advertisement solely to indicate this fact.

${ }^{1}$ To whom reprint requests should be addressed. E-mail address: lubyx001@maroon.tc.umn.edu
}

China and west to Europe via trade caravan routes popularly referred to as the "Silk Road" (Juniper et al., 1999). This flow of apple germplasm declined over the last few centuries as overland trade through the region decreased, and ceased in the 20th century as Central Asia was isolated for political reasons.

In the 1920s, Vavilov traveled through Central Asia, reporting that large wild stands of $M$. sieversii existed in specific localities, and suggested the region as a center of origin for the domesticated apple (Vavilov, 1987). Djangaliev (1977), while confirming the contemporary existence of the wild apple forests, also noted that they were under pressure in some areas because of urbanization, agriculture, grazing, and wood harvesting. In the 1980s, the U.S. Dept. of Agriculture (USDA) National Plant Germplasm System recognized that $M$. sieversii was a critical species that lacked representation in its Malus collection at the Plant Genetic Resources Unit (PGRU) in Geneva, N.Y. The material was critical because existing cultivars of the commercial apple have a narrow genetic base, with most commercial production based on very few cultivars (Hokanson et al., 1998; Kresovich et al., 
1988; Morgan and Richards, 1993; Noiton and Alspach, 1996). Malus sieversii could be a valuable genetic resource for increasing the genetic diversity of the domesticated apple for important horticultural traits (Janick et al., 1996; Korban, 1986; Way et al., 1992).

Until 1989, wild Malus germplasm from the Asian center of origin was not available (Dickson and Forsline, 1994; Forsline, 1995; Hokanson et al., 1997). In 1989, policy changes in the former Soviet Union permitted U.S. scientists to establish collaborative efforts with Central Asian counterparts to conserve this germplasm. Subsequently, with funding through the USDA National Germplasm Resources Laboratory (NGRL) and the efforts of personnel at the NGRL, the PGRU, and cooperating scientists from other institutions, contacts with scientists and government officials in Central Asian countries were initiated and collaborative collection expeditions were undertaken in 1989, 1993, 1995, and 1996. The expeditions focused mainly on Kazakhstan; the primary collaborator was Prof. Aimak Djangaliev of the Academy of Sciences of the Republic of Kazakhstan, whose laboratory had researched the variation in M. sieversii in Kazakhstan over several decades (Djangaliev, 1977). These expeditions are documented in several publications (Dickson and Forsline, 1994; Forsline, 1995, 2000; Forsline et al., 1994; Hokanson et al., 1997; U.S. Dept. of Agriculture, 2000a).

The expeditions successfully introduced large quantities of seeds, as well as a limited number of clonal accessions, to the ex situ collection at the PGRU. The collections aroused much interest among researchers in the United States, Canada, and several other countries (Table 1). Upon request to the Germplasm Curator at the PGRU, scientists were provided with samples of the collections that they are currently evaluating for various traits at their respective home locales. Extensive evaluation is also being conducted at the PGRU in collaboration with Cornell Univ. scientists. Thus, in less than a decade since the germplasm became available, a substantial international evaluation effort has been rapidly and spontaneously mobilized. In this paper we summarize progress in evaluation of the collections and prospects and plans for their utilization based on reports that were graciously provided to us by the cooperating researchers.

\section{COLLECTION}

The Central Asian M. sieversii collections are primarily from Kazakhstan, with additional samples from Kyrgyzstan, Uzbekistan, and Tajikistan. The species is a dominant overstory component in montane forests in these countries. The collection regions are designated by country, or by mountain ranges in Kazakhstan (e.g., Zailisky, Djungarsky, Karatau, Ketmen, and Talasky), as depicted in Fig. 1 and described in Table 2.

Most collections were made as seeds, and altogether over 130,000 seeds were collected from 892 trees (Table 3). Many of the seeds were taken from randomly selected trees at the collection sites, but an effort was made, especially on the 1995 and 1996 expeditions, to also identify and collect from trees that appeared to be horticulturally desirable in the field. For example, fruit size of $M$. sieversii from the different regions in Kazakhstan was diverse, but some accessions had fruit with an average diameter greater than $60 \mathrm{~mm}$, approaching the size of many commercial cultivars (Table 4). Regions 5, 9, 11, and 12 had the largest fruit that also most closely resembled the cultivated apple in other quality traits. Some trees were nearly disease-free and had other desirable horticultural characteristics. The accessions were described with 25 priority descriptors at collection time, such as excellent texture and flavor, and site data were also recorded. These records can be accessed on the Germplasm Resources Information Network (GRIN) (U.S. Dept. of Agriculture, 2000b). The accessions from each collection are designated as follows: 1989 as PI $600302-$ 600409 (GMAL 3242-3360), 1993 as PI 600423-600482 (GMAL 3526-3585), 1995 as PI 600485-600584 (GMAL 3596-4003), and 1996 as PI 600585-600624 (GMAL 4010-4317).

Fruit size and quality were not apparent each year that sites were visited. For example, in region 5 , the size and quality of the fruit were much better in 1996 than in 1995 and fruiting was observed on a much higher percentage of the trees (Table 4). Accessions with combinations of these horticulturally desirable characteristics have been des- ignated as "elite." In addition to seed from 148 elite genotypes, vegetative material was collected from 44 of the elite accessions in the 1995 and 1996 expeditions (Table 3) and placed in quarantine at the USDA Plant Quarantine Facility in Beltsville, Md.

In 1995 and 1996, material was also collected specifically for molecular studies of population genetics and biodiversity to follow preliminary work by Lamboy et al. (1996). These included randomly selected seeds from 304 trees across regions 3, 4, 5, 6, and 9 in 1995 and from 261 trees across regions 3, 4, 5, 9, 10, 11, and 12 in 1996 (Table 3). Leaves from the 261 maternal trees in 1996 also were collected and dried in silica gel, and DNA was extracted later at PGRU.

\section{DISTRIBUTION}

The distribution of seeds began in 1989 and has been tracked through GRIN (Table 3). Through 1998, the PGRU distributed over 1300 seed populations (28,300 seeds) of $M$. sieversii to 24 cooperators worldwide for evaluation. In addition, over 2000 seedlings that were resistant to apple scab in screening in New York were sent to five cooperators. Cooperators successfully germinated some 20,000 of the $28,300(71 \%)$ distributed seeds. The stratification time required for germination was highly variable, ranging from as few as $38 \mathrm{~d}$ to over $200 \mathrm{~d}$. Many cooperators noted that $M$. sieversii seeds required a longer stratification period than typically expected for domesticated apple. Following initial mortality and screening for disease resistance, or vegetative traits, over 15,000 seedlings remain in field plantings for further characterization.

The 44 clonal elite accessions remained in quarantine as of mid1999; however, permission for provisional release of 39 of the 44 accessions to the PGRU and Washington State Univ. has been granted. They have been screened for apple scab resistance by Cornell Univ. researchers in the greenhouse at the PGRU and were planted on dwarfing rootstocks in the field in 1999 and 2000 according to guidelines of the provisional release.

\section{EVALUATION}

Over 50 scientists and technicians with diverse expertise are evaluating $M$. sieversii accessions at locations in several countries (Table 1). Most trees held by cooperators are not yet fruiting, so evaluation has focussed on disease resistance or vegetative traits. Currently, HortResearch in New Zealand and the PGRU are the only sites with large numbers of fruiting trees. Most evaluators intend to evaluate the accessions for standard fruit traits, such as size, color, texture, aroma and flavor, and vegetative traits, such as growth habit and vigor, as well as disease and pest resistances and other traits related to adaptation in their region. These plans are summarized in Table 1. Progress for some traits is discussed below.

\section{Disease and pest resistance}

Apple scab. Several cooperators are screening young seedlings for apple scab [Venturia inaequalis (Cooke) Wint.]. In New Jersey, nearly 2000 seedlings were screened for apple scab, and Goffreda (pers. comm., 1999) reported that a high proportion exhibited resistance similar to that conferred by the $\mathrm{V}_{\mathrm{r}}$ gene. In New York (Aldwinckle et al., 1997), over 4000 seedlings from each of the 12 regions (Fig. 1 and Table 3) have been evaluated for apple scab resistance; a total of $27 \%$ of those screened are resistant (Table 5). Combining data from screenings of material collected in all the expeditions revealed major variations in the incidence of apple scab resistance related to region of origin (Table 5). This trend was also observed previously with a smaller subset (Aldwinckle et al., 1997). Region 4 had the highest proportion (49\%) of resistant seedlings while region 10 had the lowest proportion $(6 \%)$.

In New Zealand, over 2500 seedlings from 60 seed lots from the 1995 and 1996 expeditions were evaluated in the greenhouse (Table 5 ). About $24 \%$ of the seedlings were resistant in these evaluations, ranging among half-sib families from $0 \%$ to $70 \%$. Regions 3,10 , and 11 had less than $10 \%$ resistant seedlings while regions $4,5,6$, and 9 had greater than $25 \%$ resistant seedlings (Table 5). 
Table 1. Researchers evaluating Malus sieversii collected in Central Asia.

\begin{tabular}{|c|c|c|c|}
\hline Name & Organization and location & Expertise of evaluators & Traits of special interest in $M$. sieversii ${ }^{\mathrm{z}}$ \\
\hline Jennifer McBeath & Univ. of Alaska, Fairbanks. & Horticulture & Cold hardiness \\
\hline Curt Rom & Univ. of Arkansas, Fayetteville. & Breeding, pomology & High chilling requirement, fruit traits \\
\hline Cecil Stushnoff & Colorado State Univ., Fort Collins. & Plant breeding, physiology & Cold hardiness \\
\hline Schuyler Korban & Univ. of Illinois, Urbana & Plant breeding & Project terminated \\
\hline Joe Hecksel & Private Grower, Eaton Rapids, Mich. & Pomology & Horticultural traits \\
\hline $\begin{array}{l}\text { James Luby, } \\
\text { David Bedford }\end{array}$ & Univ. of Minnesota, St. Paul. & Plant breeding, pomology & $\begin{array}{l}\text { Resistance to apple scab and fire blight, cold hardiness, } \\
\text { fruit traits }\end{array}$ \\
\hline John Kreutziger ${ }^{z}$ & Heartland Germplasm, York, Nebr. & Plant breeding & $\begin{array}{l}\text { Disease and pest resistance, late flowering and leafing } \\
\text { dates, fruit traits }\end{array}$ \\
\hline Joseph Goffreda & $\begin{array}{l}\text { Rutgers Fruit Research and Ext. } \\
\text { Center, New Brunswick, N.J. }\end{array}$ & Plant breeding & $\begin{array}{l}\text { Resistance to apple scab, fire blight, and cedar apple rust, } \\
\text { fruit traits and storage ability }\end{array}$ \\
\hline $\begin{array}{l}\text { Philip Forsline, } \\
\text { Warren Lamboy, } \\
\text { Stan Hokanson, } \\
\text { Jing Yu }\end{array}$ & $\begin{array}{l}\text { USDA, ARS, Plant Genetic Res. } \\
\text { Unit, Geneva, N.Y. }\end{array}$ & $\begin{array}{l}\text { Pomology, physiology, } \\
\text { plant pathology, } \\
\text { molecular genetics }\end{array}$ & $\begin{array}{l}\text { Resistance to apple scab, } \\
\text { fire blight, and cedar apple rust, fruit traits, molecular } \\
\text { genetic studies of genetic diversity }\end{array}$ \\
\hline $\begin{array}{l}\text { Herb Aldwinckle, } \\
\text { Tim Momol, } \\
\text { Sang-Bum Lee, } \\
\text { Ki-Sung Ko }\end{array}$ & $\begin{array}{l}\text { Cornell Univ., Dept. of Plant } \\
\text { Pathology, Geneva, N.Y. }\end{array}$ & Plant pathology & $\begin{array}{c}\text { Resistance to apple scab, fire blight, cedar apple rust, } \\
\text { Rosellinia necatrix, and Helicobasidium mompa }\end{array}$ \\
\hline $\begin{array}{l}\text { Susan Brown, } \\
\text { Norman Weeden }\end{array}$ & $\begin{array}{l}\text { Cornell Univ., Dept. of Hort Sci., } \\
\text { Geneva, N.Y. }\end{array}$ & $\begin{array}{l}\text { Plant breeding, } \\
\text { molecular genetics }\end{array}$ & Dwarf growth habit \\
\hline Ian Merwin & $\begin{array}{l}\text { Cornell Univ., Dept. of Fruit and } \\
\text { Veg. Sci., Ithaca, N.Y. }\end{array}$ & Pomology & Resistance to soil borne apple replant pathogens \\
\hline Harvey Reissig & $\begin{array}{l}\text { Cornell Univ., Dept of Entomol, } \\
\text { Geneva, N.Y. }\end{array}$ & Entomology & Resistance to apple maggot \\
\hline $\begin{array}{l}\text { David Ferree, } \\
\text { Diane Miller }\end{array}$ & $\begin{array}{l}\text { Ohio Agr. Res. and Dev. Center, } \\
\text { Wooster, Ohio }\end{array}$ & Pomology & $\begin{array}{l}\text { Resistance to apple scab, cedar apple rust, and fire blight, } \\
\text { late flowering, fruit traits }\end{array}$ \\
\hline Donald Hendricks & The Dawes Arboretum, Newark, Ohio & Botany & $\begin{array}{l}\text { Resistance to apple scab, cedar apple rust, and fire blight, } \\
\text { late flowering, fruit traits }\end{array}$ \\
\hline Mitch Lynd & $\begin{array}{l}\text { Private Grower, Midwest Apple Impr. } \\
\text { Assn., Johnstown, Ohio }\end{array}$ & Pomology, botany & $\begin{array}{l}\text { Resistance to apple scab, cedar apple rust, and fire blight, } \\
\text { late flowering, fruit traits }\end{array}$ \\
\hline Bruce Barritt & Washington State Univ., Wenatchee & Breeding, pomology & $\begin{array}{l}\text { Resistance to pests, fire blight and powdery mildew, } \\
\text { juvenility, cold hardiness, sunburn tolerance, fruit traits }\end{array}$ \\
\hline Kevin Bradley & Private Grower, Madison, Wis. & Pomology & Horticultural traits \\
\hline Brian Smith & Univ. of Wisconsin, River Falls. & Breeding, pomology & $\begin{array}{l}\text { Disease resistance, yield, manageable tree stature and } \\
\text { habit, winter hardiness, late bloom, short juvenility, } \\
\text { early fruit maturity, fruit traits }\end{array}$ \\
\hline $\begin{array}{l}\text { Cheryl Hampson, } \\
\text { Harvey Quamme }\end{array}$ & $\begin{array}{l}\text { Agriculture and Agri-Food Canada, } \\
\text { Summerland, British Columbia, } \\
\text { B.C., Canada }\end{array}$ & $\begin{array}{l}\text { Plant breeding, cold } \\
\text { hardiness physiology }\end{array}$ & Disease resistance, cold hardiness, drought tolerance \\
\hline Campbell Davidson & $\begin{array}{l}\text { Agriculture and Agri-Food Canada, } \\
\text { Morden, Man., Canada }\end{array}$ & Plant breeding & Resistance to fire blight, cold hardiness, fruit traits \\
\hline Daryl Hunter & $\begin{array}{l}\text { Kings Landing Historical Corp., } \\
\text { Fredricton, N.B., Canada }\end{array}$ & Pomology & Horticultural traits \\
\hline $\begin{array}{l}\text { Christianne Deslauriers, } \\
\text { Charles Embree }\end{array}$ & $\begin{array}{l}\text { Agriculture and Agri-Food Canada, } \\
\text { Kentville, N.S., Canada }\end{array}$ & Plant breeding, physiology & Disease resistance, cold hardiness, growth habit, fruit traits \\
\hline $\begin{array}{l}\text { Rolf Büttner, } \\
\text { Martin Geibel }\end{array}$ & Genebank for Fruit, Dresden, Germany & Pomology, plant breeding & $\begin{array}{l}\text { Resistance to apple scab and powdery mildew (including } \\
\text { molecular markers), plant stature, length of vegetative } \\
\text { period, fire blight, fruit characters, genetic diversity for } \\
\text { molecular and morphological traits }\end{array}$ \\
\hline $\begin{array}{l}\text { Hideo Bessho, } \\
\text { Junichi Soejima }\end{array}$ & $\begin{array}{l}\text { Ministry of Agr., Forestry and } \\
\text { Fisheries, Yamanishi, Japan }\end{array}$ & Plant breeding & Horticultural traits \\
\hline $\begin{array}{l}\text { Vincent Bus, } \\
\text { Nadozie Oraguzie }\end{array}$ & HortResearch, Havelock North, N.Z. & $\begin{array}{l}\text { Plant breeding, genetics, } \\
\text { plant pathology, } \\
\text { entomology, biometrics }\end{array}$ & $\begin{array}{l}\text { Resistance to apple scab, powdery mildew, fire blight, } \\
\text { woolly apple aphid, leafroller, apple leaf curling midge, } \\
\text { leafing and flowering dates, juvenility, burr knots, } \\
\text { stooling ability, tree habit and vigor, fruit traits }\end{array}$ \\
\hline Dag Roen & $\begin{array}{l}\text { The Norwegian Crop Res. Inst., } \\
\text { Hermansverk, Norway }\end{array}$ & Plant breeding & $\begin{array}{l}\text { Resistance to apple scab and powdery mildew, fruit traits } \\
\text { and storage ability, fruit rots and disorders }\end{array}$ \\
\hline Rita Farrel & Univ. of Reading, Reading, U.K. & Botany, molec. genetics & Genetic diversity \\
\hline Barrie Juniper & Univ. of Oxford, Oxford, U.K. & Botany, molec. genetics & Origin of domesticated apple \\
\hline Taiiboos Human & $\begin{array}{l}\text { INFRUITEC, Stellenbosch, } \\
\text { South Africa }\end{array}$ & Plant breeding, pomology & $\begin{array}{l}\text { Resistance to woolly apple aphid, Phytophthora, apple } \\
\text { scab, powdery mildew and drought, chilling } \\
\text { requirement, sunburn tolerance, fruit traits }\end{array}$ \\
\hline Gary Britz & $\begin{array}{l}\text { MULTIFRUIT EPPINDUST, } \\
\text { South Africa }\end{array}$ & & \\
\hline
\end{tabular}

${ }^{\text {zDeceased June } 1999 .}$

y Currently at Montana State Univ., Bozeman. 


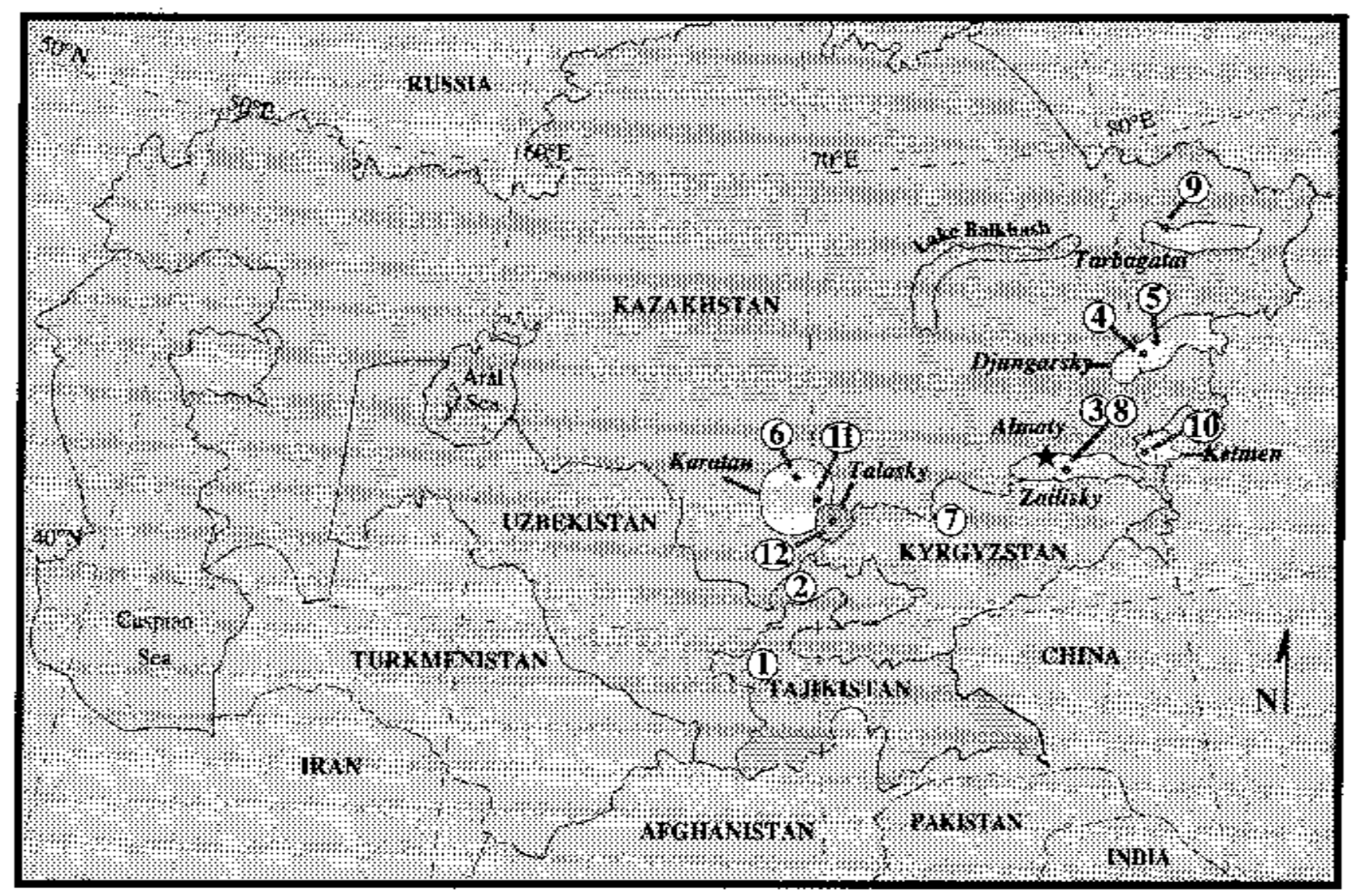

Fig. 1. Map of Central Asia showing 12 regions where Malus sieversii germplasm was collected in 1989, 1993, 1995, and 1996.

Table 2. Site descriptions for Malus sieversii collection regions in Central Asia.

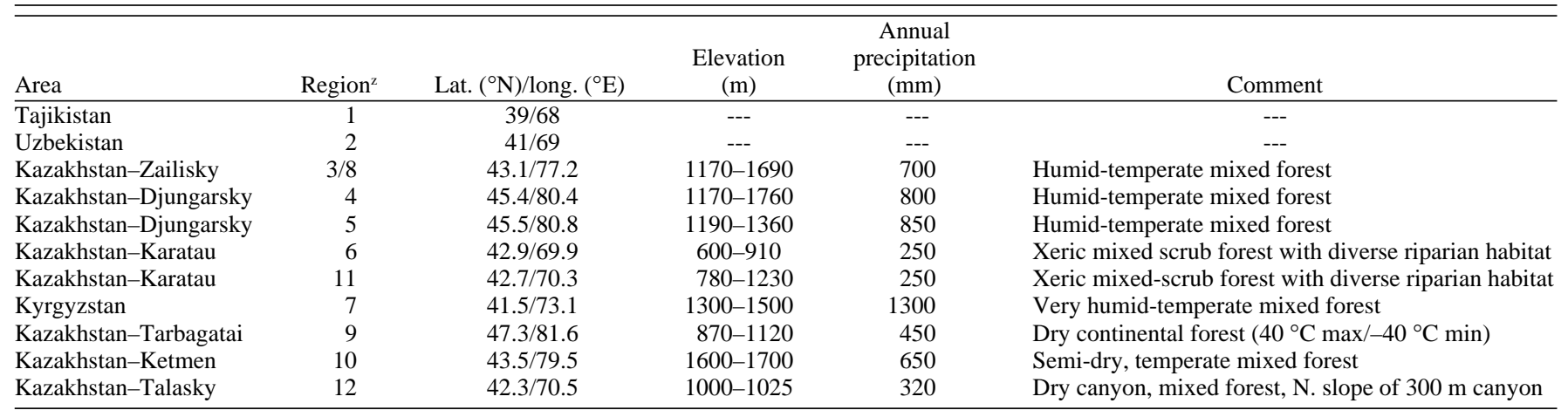

Table 3. Malus sieversii inventory of seeds used (for seedlings under evaluation); seeds in long-term storage (-196 $\left.{ }^{\circ} \mathrm{C}\right)$ at the USDA National Seed Storage Lab (NSSL) at Fort Collins, Colo.; seeds in medium-length storage $\left(-20^{\circ} \mathrm{C}\right)$ at the USDA Plant Genetic Resources Unit (PGRU) at Geneva, N.Y.; and from collection trips over 4 years.

\begin{tabular}{|c|c|c|c|c|c|c|}
\hline \multirow[b]{2}{*}{ Collection } & \multirow{2}{*}{$\begin{array}{c}\text { Seeds } \\
\text { collected }\end{array}$} & \multirow{2}{*}{$\begin{array}{l}\text { Trees represented } \\
\text { in seed collections }\end{array}$} & \multirow[b]{2}{*}{ Regions visited $^{z}$} & \multicolumn{3}{|c|}{ No. seeds } \\
\hline & & & & Used or distributed & At NSSL & $\overline{\text { At PGRU }}$ \\
\hline 1989 & 11,000 & 119 & $1,2,3$ & 1,200 & 3,600 & 6,200 \\
\hline 1993 & 22,000 & 60 & $3,4,5,6,7,8$ & 7,000 & 7,300 & 7,700 \\
\hline 1995 (random) & 14,000 & 304 & $3,4,5,6,9$ & 2,200 & 3,300 & 8,500 \\
\hline 1996 (elite) & 21,000 & $44^{x}$ & $4,5,9,10,11,12$ & 4,900 & 5,000 & 11,100 \\
\hline 1996 (random) & 16,000 & $261^{\mathrm{w}}$ & $3,4,5,9,10,11,12$ & 1,900 & 3,500 & 10,600 \\
\hline Total & 130,000 & 892 & --- & 28,300 & 39,500 & 62,200 \\
\hline
\end{tabular}

${ }^{2}$ Collection regions described in Fig. 1 and Table 2.

${ }^{\mathrm{y}} 14$ accessions also collected and established as clones.

$\times 30$ accessions also collected and established as clones.

${ }^{\text {w }}$ Leaves of mother trees collected and DNA extracted. 
Table 4. Region and year of collection and mean and range for fruit size in samples from elite or random Malus sieversii trees measured during collection in Kazakhstan.

\begin{tabular}{lccc}
\hline & & \multicolumn{2}{c}{ Mean (range) fruit diam $(\mathrm{mm})$} \\
\cline { 3 - 4 } Region $^{\mathrm{z}}$ & Year(s) & Elite & Random \\
\hline 12 & 1996 & $65(60-74)$ & $42(32-50)$ \\
5 & 1996 & $58(54-65)$ & $35(25-49)$ \\
9 & $1995 / 96$ & $56(46-72)$ & $43(28-62)$ \\
11 & 1996 & $55(44-76)$ & $42(29-63)$ \\
10 & 1996 & $49(47-51)$ & $40(29-51)$ \\
5 & 1995 & $46(37-56)$ & $36(27-48)$ \\
3 & $1995 / 96$ & $45(32-56)$ & $34(25-49)$ \\
4 & $1995 / 96$ & $44(32-55)$ & $34(28-44)$ \\
6 & 1995 & $42(33-46)$ & $41(28-54)$ \\
\hline${ }^{2}$ See Fig 1 and Table 2 for descriptions of
\end{tabular}

${ }^{\mathrm{z}}$ See Fig. 1 and Table 2 for descriptions of collection regions.

Table 5. Apple scab resistance of Malus sieversii seedlings from 12 regions in Central Asia screened in greenhouses in New York (NY; 1993, 1995, and 1996 collections), New Zealand (NZ; 1995 and 1996 collections), and Minnesota (MN; 1995 collection).

\begin{tabular}{|c|c|c|c|c|c|c|}
\hline \multirow[b]{3}{*}{ Region $^{z}$} & \multicolumn{6}{|c|}{ Seedlings } \\
\hline & \multicolumn{3}{|c|}{ Screened (no.) } & \multicolumn{3}{|c|}{ Resistant (\%) } \\
\hline & $\mathrm{NY}$ & $\mathrm{NZ}$ & $\mathrm{MN}$ & $\mathrm{NY}$ & $\mathrm{NZ}$ & $\mathrm{MN}$ \\
\hline$\overline{1}$ & 21 & --- & --- & 5 & --- & $\overline{---}$ \\
\hline 2 & 101 & --- & --- & 24 & --- & --- \\
\hline 3 & 450 & 262 & --- & 17 & 8 & --- \\
\hline 4 & 369 & 287 & --- & 49 & 28 & --- \\
\hline 5 & 1175 & 277 & --- & 27 & 45 & --- \\
\hline 6 & 705 & 133 & 362 & 37 & 25 & 74 \\
\hline 7 & 383 & --- & --- & 25 & --- & --- \\
\hline $8^{y}$ & 151 & --- & --- & 07 & --- & --- \\
\hline 9 & 1125 & 684 & 1171 & 27 & 29 & 62 \\
\hline 10 & 123 & 86 & --- & 06 & 2 & --- \\
\hline 11 & 226 & 244 & --- & 23 & 5 & --- \\
\hline 12 & 133 & --- & --- & 14 & --- & --- \\
\hline Total & 4971 & 1973 & 1533 & 27 & 24 & 65 \\
\hline
\end{tabular}

${ }^{\mathrm{z}}$ Regions described in Fig. 1 and Table 2.

ypen-pollinated seedlings from trees in the ex situ collection at Almaty (Kazakhstan) Botanical Garden.

In Minnesota, seedlings from regions 6 and 9 were screened and $65 \%$ were resistant (Table 5). The regions were similar, but individual families contained from $0 \%$ to $88 \%$ resistant seedlings.

Several seed lots have been screened at multiple sites (Table 6). Although some families consistently produced high proportions of resistant seedlings (e.g., GMAL 3607, 3631, 4024, 4089, and 4177) or high proportions of susceptible seedlings (GMAL 3609, 3643, 4011, 4068, 4071, 4086, 4171, 4309, and 4315) over multiple sites, others were quite variable. Inconsistencies in the seedling screenings may be due to different local inoculum sources, or to sampling effects from small sample sizes for some accessions at some locations. Alternatively, they may reflect variation in age or physiological state of seedlings or different test conditions that could influence infection success.

In New Zealand, Bus et al. (pers. comm.) also evaluated over 1400 trees from 52 seed lots from the 1993 expedition, following natural apple scab infection in the field. These trees form part of a large population of seedlings for breeding to increase genetic diversity for many traits (Noiton and Shelbourne, 1992). Using estimated variance components, they found a low heritability ( 0.13 on a family mean basis), mainly because of high levels of resistance and little variation among these families. They detected no significant differences for scab incidence among the collection regions.

Of the 39 elite clonal accessions granted provisional release from quarantine, nine have been evaluated for apple scab resistance in the greenhouse using replicate, grafted plants. In three of these accessions, apple scab resistance is evident in all 10 replicate trees. Some trees of five other accessions were resistant. In addition, Mehlenbacher and Weeden (pers. comm.) extracted DNA from five elite accessions, $40 \%$ or more of whose offspring were resistant to apple scab, and screened for the presence of markers that had been linked to apple scab resistance genes in other Malus accessions. All five M. sieversii had
Table 6. Apple scab resistance of Malus sieversii seedlings in Central Asia from seed lots evaluated in greenhouses in New York (NY), New Zealand (NZ), and Minnesota $(\mathrm{MN})$ after inoculation with local strains of Venturia inaequalis.

\begin{tabular}{|c|c|c|c|c|c|c|}
\hline \multirow{3}{*}{$\begin{array}{l}\text { GMAL / PI } \\
\text { accession no. }^{z}\end{array}$} & \multicolumn{6}{|c|}{ Seedlings } \\
\hline & \multicolumn{3}{|c|}{ Screened (no.) } & \multicolumn{3}{|c|}{ Resistant (\%) } \\
\hline & $\mathrm{NY}$ & $\mathrm{NZ}$ & $\mathrm{MN}$ & NY & $\mathrm{NZ}$ & $\overline{\mathrm{MN}}$ \\
\hline $3604 / 600493$ & 8 & 42 & 23 & 12 & 26 & 78 \\
\hline 3605 / 600494 & 11 & 20 & 44 & 45 & 40 & 55 \\
\hline 3607 / 600496 & 15 & 38 & 24 & 60 & 68 & 92 \\
\hline 3608 / 600497 & 14 & 23 & 13 & 50 & 26 & 0 \\
\hline 3609 / 600498 & 14 & 35 & --- & 7 & 9 & --- \\
\hline $3618 / 600507$ & 8 & 40 & 20 & 38 & 8 & 60 \\
\hline 3625 / 600514 & 15 & 38 & 36 & 73 & 8 & 53 \\
\hline 3627 / 600516 & 13 & 42 & 9 & 54 & 55 & 56 \\
\hline $3631 / 600520$ & 14 & 45 & 38 & 71 & 62 & 58 \\
\hline 3634 / 600523 & 14 & 39 & 34 & 29 & 49 & 85 \\
\hline $3636 / 600525$ & 14 & 37 & 19 & 71 & 24 & 90 \\
\hline 3643 / 600532 & 15 & 48 & 40 & 13 & 0 & 57 \\
\hline 3683 / 600571 & 15 & 38 & 27 & 60 & 45 & 78 \\
\hline 3688 / 600574 & 13 & 32 & --- & 62 & 19 & --- \\
\hline 3691 / 600577 & 15 & 36 & --- & 27 & 25 & --- \\
\hline 4011 / 600586 & 24 & 43 & --- & 0 & 2 & --- \\
\hline 4024 / 600598 & 26 & 49 & --- & 62 & 59 & --- \\
\hline 4032 / 600606 & 24 & 35 & --- & 33 & 46 & --- \\
\hline 4038 / 600609 & 24 & 40 & --- & 38 & 48 & --- \\
\hline 4068 / --- & 7 & 19 & --- & 14 & 0 & --- \\
\hline 4071 / --- & 5 & 24 & --- & 0 & 4 & --- \\
\hline $4086 /$--- & 7 & 22 & --- & 0 & 0 & --- \\
\hline 4089 / --- & 5 & 15 & --- & 80 & 53 & --- \\
\hline $4171 /$--- & 6 & 20 & --- & 0 & 5 & --- \\
\hline 4177 / --- & 5 & 17 & --- & 100 & 65 & --- \\
\hline $4190 /$--- & 7 & 23 & --- & 29 & 70 & --- \\
\hline 4209 / --- & 6 & 19 & --- & 67 & 32 & --- \\
\hline 4302 / --- & 5 & 13 & --- & 0 & 23 & --- \\
\hline 4309 / --- & 7 & 24 & --- & 0 & 0 & --- \\
\hline $4315 /$--- & 7 & 17 & --- & 0 & 0 & --- \\
\hline
\end{tabular}

${ }^{\mathrm{z}}$ GMAL 4068-4315 are from the random collections with small seedlot quantities; PI numbers were not assigned to these accessions.

RAPD markers $\mathrm{P} 415 \mathrm{~B}$ and UBC562 for the $V_{r}$ resistance gene. However, since these markers were also present in many other accessions, including susceptible ones, they may be of little value. Four of these five accessions also contained one or more markers that were quite rare in germplasm that did not exhibit apple scab resistance. Accessions GMAL 4326 (Q35771), GMAL 4331 (Q35777), and GMAL 4334 (Q35780) had marker OPB12 for $V_{m}$, and GMAL 4327 (Q35772) had marker OPB12 for $V_{m}$, the CS5 marker for $V_{f}$ and the UBC220 marker for $V_{b}$. Since the elite selections were initially identified, when collected in Kazakhstan, based on their superior fruit traits, these accessions represent potentially new sources of multiple resistance genes in a horticulturally desirable background.

Fire blight. Extensive evaluations for fire blight (Erwinia amylovora E.F. Smith) resistance have been conducted in New York and New Zealand. In a cooperative program of Cornell Univ. and PGRU (Momol et al., 1999), 1125 seedlings from the 1989 and 1993 expeditions were inoculated with fire blight, and $29 \%$ were resistant. Work is in progress to screen subsequent collections. One fire blightresistant seedling, GMAL 3280.h, had desirable fruit quality and large fruit size (56-mm diameter). These results are significant because we have identified a resistant genotype with desirable horticultural traits.

In New Zealand, 936 trees from the 1993 expedition were evaluated in their fifth leaf for fire blight susceptibility following natural infection in the orchard. About $13 \%$ of the trees were infected in this field evaluation, while Momol et al. (1999) found that 33\% of 775 seedlings from the same 1993 collection expedition were resistant when inoculated as young seedlings. Momol et al. (1999) observed that seedlings from regions 3 and 6 were more susceptible than those from regions 4,5 , and 7 , whereas no differences were observed in New Zealand following natural infection.

In New Zealand, two of the most susceptible families (PI600479 and PI600480) were from a single site in Kyrgyzstan (region 7). Of the six most resistant families, three (PI600428, PI600429, and PI600444) 
were from region 4 in east central Kazakhstan, and two (PI600468 and PI600476) were from region 6 in south central Kazakhstan. Inoculations of young seedlings by Momol et al. (1999) showed that PI600468 was among the more resistant families. However, in contrast with the New Zealand field results, Momol et al. (1999) found PI 600480 to be among the more resistant, but PI600429 and PI600444 among the more susceptible families. These apparent contradictions may result from a difference in natural vs. artificial inoculation techniques, physiological differences in the trees due to age, genetic differences in the seed lots due to sampling, or different pathogen races.

Apple replant pathogens. In New York, Isutsa and Merwin (2000) evaluated some $M$. sieversii accessions, as well as other Malus species, for their resistance or tolerance to apple replant pathogens (ARP), based on their relative biomass accumulation when grown in orchard soils. The ARP included various Pythium, Cylindrocarpon, Fusarium, Rhizoctonia, and Phytophthora species, as well as nematodes. Seedlings from two families (PI600427 and PI600563) were categorized as tolerant of ARP.

Powdery mildew. In Germany and New Zealand, all seedlings are being evaluated for resistance to powdery mildew [Podosphaera leucotricha (Ell. \& Ev.) E.S. Salmon]. In Germany, the juvenile susceptibility to powdery mildew decreased significantly as plants aged. Nearly all plants were susceptible when evaluated in the first season of growth, but mildew infections in 1998 were only $70 \%$ in the 2-year-old plants and $45 \%$ in the 3 -year-old plants over all populations. Depending on the accession, from $10 \%$ to $60 \%$ of the plants in a family were resistant.

Other diseases. Seedling evaluations for resistance to cedar apple rust (Gymnosporangium juniperi-virginianae Schwein.) are being conducted in New York and New Jersey. In New York, $\approx 30 \%$ of over 3000 seedlings screened were resistant. In New York, Lee, Ko, and Aldwinckle (pers. comm.) have screened seedlings for resistance to western white root rot (Rosellinia necatrix Prill.) and violet root rot (Helicobasidium mompa Tanaka) diseases and identified some populations with apparent resistance; these are being evaluated further.

Insect resistance. In New York, Reissig (pers. comm., 1999) conducted laboratory studies to compare the oviposition preference and survival of the apple maggot (Rhagoletis pomonella Walsh) in fruit from seedlings of $M$. sieversii. During the 2 years of the study, fruit from 43 different seedlings were evaluated from material collected in 1989. Oviposition preference was compared by picking the fruit in July and exposing the selections, along with fruit from 'McIntosh', to groups of apple maggot females from a laboratory colony in clear Plexiglas cages, and counting subsequent oviposition punctures and eggs in the fruit. Oviposition occurred in fruit from all of the $M$. sieversii seedlings tested, but fruit was generally less infested than the 'McIntosh' fruit by $3 \%$ to $94 \%$.

Apple maggot females also infested fruit from each seedling in a "no-choice" test. After infestation, fruit was incubated on racks over water-filled dishes and exiting larvae were collected to compare survival rates. Larvae survived in fruit from all of the selections tested, but numbers of larvae surviving in the $M$. sieversii fruit were generally lower than in 'McIntosh' standards. Although many of the M. sieversii selections were less favorable for apple maggot oviposition and survival than 'McIntosh', most of the fruit were somewhat smaller (average 2.1-3.3 cm in diameter) than 'McIntosh' fruit (average 4.3 $\mathrm{cm}$ in diameter). Additional studies are needed to determine if the observed differences between these selections and the standard fruit are due to physical characteristics or chemical factors.

In New Zealand, seedlings from the 1993 collection were evaluated for resistance to woolly apple aphid (Eriosoma lanigerum Hausmann) in order to estimate heritabilities and combining abilities and identify resistant genotypes. In a preliminary study on trees grown from root cuttings from a subset of the 1993 seedlings, resistance to light brown apple moth (Epiphyas postvittana Walker) and apple leaf curling midge (Dasyneura mali Kieff.) was investigated. The findings were inconclusive, perhaps because the screening technique was based on leaf damage rather than development or survival rates (Wearing and Colhoun, 1999). However, the indication of a strong genetic component in the variation for incidence of apple leaf curling midge warrants further research.
Multiple resistance. Several cooperators are screening seedlings for resistance to multiple diseases and pests. Some genotypes with resistance to multiple diseases have already been identified. In New York, for example, 775 seedlings from 33 seed lots collected in 1993 from regions $3,4,5,6,7$, and 8 were inoculated with apple scab, cedar apple rust, and fire blight pathogens. Of these seedlings, $23 \%$ were resistant to apple scab (Aldwinckle et al., 1997), 38\% to cedar apple rust and 33\% to fire blight (Momol et al., 1997). As a result of these multiple screens for disease resistance, 207 seedlings with putative multiple resistance were selected from the original 775 for further horticultural evaluation.

Researchers in Germany noted that every population evaluated included some plants that were resistant to apple scab and powdery mildew. After 2 years of evaluation, a total of 64 plants from nearly 1100 seedlings had no symptoms of either scab or powdery mildew.

In New Zealand, multiple-disease resistant accessions with good eating quality will be selected for breeding purposes upon completion of the resistance and fruit evaluations.

\section{Environmental stress tolerance}

Cold hardiness. Several cooperators are interested in cold hardiness and will be evaluating material in the field at high latitude sites. Most material is too young to be evaluated, but all seedlings planted at Fairbanks, Alaska, were killed in their first winter.

In Colorado, Stushnoff (pers. comm.) has screened young seedlings using the following acclimation protocol followed by a laboratory freezing test (Stushnoff et al., 1983). When seedlings grown in flats were 3 to $5 \mathrm{~cm}$ tall they were exposed to short days (12 h) at 10 ${ }^{\circ} \mathrm{C}$ for 1 week, followed by 2 weeks at $4{ }^{\circ} \mathrm{C}$, and an overnight frost of $-5^{\circ} \mathrm{C}$, and then returned to $10^{\circ} \mathrm{C}$ day $/ 4^{\circ} \mathrm{C}$ night with 12 -h daylength for 1 week. The entire flat was then frozen, with the temperature falling at a rate of $2{ }^{\circ} \mathrm{C} / \mathrm{h}$ to $-30{ }^{\circ} \mathrm{C}$ and held for $1 \mathrm{~h}$. The seedlings were then grown in a greenhouse and evaluated for injury by comparing them with 'Kerr' open-pollinated seedlings. All seedlings with $75 \%$ or greater dieback were considered not hardy. Of 720 seedlings evaluated, 86 were considered hardy and have been retained for field evaluation.

Chilling requirement and late bloom. In South Africa, genotypes with shorter chilling requirements are sought for production areas with warm winters (Human, pers. comm.). Conversely, several cooperators in the central United States are seeking to identify material with late bloom to avoid spring frosts. Researchers at these sites have been particularly interested in seedlings germinating after long periods in stratification, as this trait has been correlated with long chilling requirement and late bloom (Mehlenbacher and Voordeckers, 1991). The chilling required for seed germination varied considerably, ranging from $38 \mathrm{~d}$ in Germany to over $200 \mathrm{~d}$ in Nova Scotia.

Material collected in 1993 may be especially appropriate for this objective, since only $\approx 2 \%$ of the trees in Kazakhstan bore fruit that year, following a late spring frost. A total of 173 seedlings with multiple disease resistance that were screened at Cornell Univ. (Aldwinckle et al., 1997; Momol et al., 1997) are under evaluation at the Dawes Arboretum in Ohio in an area that is often challenged by early spring frosts. In addition, 787 seedlings from the 1995 and 1996 collections, identified as having long seed-chilling requirement (104 to $127 \mathrm{~d}$ ) at PGRU, were sent to Ohio.

Drought tolerance and sunburn resistance. In warm, arid production regions, such as Washington, British Columbia and South Africa, cooperators indicated an interest in screening for drought tolerance. Malus sieversii is recognized as a drought-tolerant rootstock in Kazakhstan and China. Regions 6, 11, and 12, in particular, have a hot, arid climate with high insolation (Table 2). Sunburn was surprisingly rare on fruit collected in these areas.

\section{Plant growth habit}

Several cooperators indicated they were interested in obtaining trees with specific growth habits. Dr. Susan Brown in New York is interested in obtaining genetic dwarfs and is evaluating seedlings from three accessions that Kazakh scientists described as dwarfs. In New 
Zealand, the seedlings in the apple genetics population are rated for tree habit using the descriptors from the International Board for Plant Genetic Resources (IPBGR), and girth is assessed as a measure of vigor.

\section{DNA sequence diversity}

Studies of genetic diversity in the Central Asian material at simple sequence repeat sites are continuing at the PGRU as a continuation of previous studies (Hokanson et al., 1998; Lamboy et al., 1996). In an initial study, Lamboy et al. (1996) reported that most allelic variation was among families within collection regions rather than among regions. The main objectives of the ongoing studies are to characterize: 1) relative levels of diversity among and within populations; 2) variation between collecting years (1995 and 1996) at the same sites; and 3) diversity among maternal genotypes vs. that of the openpollinated seedling populations derived from them, using leaves and seeds collected in 1996. Several other cooperators plan studies of DNA sequence diversity (Table 1). The Oxford Univ. group is investigating the origin and migrations of the apple, including $M$. sieversii and its ancestors, in a comprehensive program using molecular markers as well as geological, historical, and anthropological approaches (Juniper et al., 1999).

\section{UTILIZATION}

The cooperators represent groups interested in cultivar development and genetic diversity, including genebank programs in the United States, Germany, and New Zealand, and universities, government agencies, government-held corporations, and consortia of apple growers that conduct breeding programs (Table 1). Since most seedlings held by cooperators are not yet fruiting, evaluation is ongoing and they have not yet been used in breeding. Many indicated their intentions for utilization, however. Nearly all cooperators viewed the $M$. sieversii germplasm as a means to broaden the genetic diversity in their breeding programs. Many cooperators indicated that they planned to use $M$. sieversii selections in further breeding for rootstocks or scion varieties. Most cooperators sought: 1) novel fruit quality characters, such as color, texture, aroma, and flavor; 2) new sources for disease or pest resistance; and 3) stress tolerance for adaptation to their production regions. In addition, several were seeking easily managed growth habits for scion or rootstock cultivars.

The value of the $M$. sieversii germplasm in cooperators' breeding programs will not be known for many years. The ongoing evaluations will ensure that it is tested for critical traits in a wide range of apple production regions. We anticipate that this germplasm will ultimately offer useful genetic diversity for several reasons. First, the ecological amplitude of the species in its native habitats is truly impressive. Samples were collected from diverse ecosystems, ranging from lush, humid, temperate forests to sparse dry, cold, northern forests to xeric, near-desert habitats (Table 2). Potential ecotypes from these regions should offer environmental adaptation as rootstock or scion for most apple production regions, except subtropical areas. Second, M. sieversii in its native habitat has coevolved with several pathogenic organisms. Apple scab and codling moth (Cydia pomonella L.) were especially noted in collection sites. Other organisms, such as ubiquitous apple replant pathogens, are probably present in the montane apple forests, and natural selection for resistance may have resulted as a consequence of forest regeneration. Finally, some $M$. sieversii genotypes will be readily useful because they are already similar in phenotype to commercial cultivars for some critical horticultural traits. The elite clonal accessions and similar seedlings that will be discovered during evaluation may contribute to new cultivars without extensive backcrossing.

\section{Literature Cited}

Aldwinckle, H.S., P.L. Forsline, H.L. Gustafson, and S.C. Hokanson. 1997. Evaluation of apple scab resistance of Malus sieversii populations from Central Asia. HortScience 32:440.
Dickson, E.E. and P.L. Forsline. 1994. Collection of wild apple in Middle Asia. Malus 8:11-14.

Djangaliev, A.D. 1977. The wild apple tree of Kazakhstan (in Russian). Nauka Publishing House of Kazakh SSR., Alma Ata, Kazakhstan.

Forsline, P.L. 1995. Adding diversity to the National Apple Germplasm Collection; Collecting wild apple in Kazakhstan. New York Fruit Quart. 3:3-6.

Forsline, P.L. 2000. Procedures for collection, conservation, evaluation and documentation of germplasm using Malus as an example. Acta Hort. 522:223-234

Forsline, P.L., E.E. Dickson, and A.D. Djangaliev. 1994. Collection of wild Malus, Vitis and other fruit species genetic resources in Kazakhstan and neighboring republics. HortScience 29:433.

Hokanson, S.C., P.L. Forsline, J.R. McFerson, W.F. Lamboy, H.S. Aldwinckle, J.J. Luby, and A.D. Djangaliev. 1999. Ex situ and in situ conservation strategies for wild Malus germplasm in Kazakhstan. Acta Hort. 484:85-91.

Hokanson, S.C., J.R. McFerson, P.L. Forsline, W.F. Lamboy, J.J. Luby, H.S. Aldwinckle, and A.D. Djangaliev. 1997. Collecting and managing wild Malus germplasm in its center of diversity. HortScience 32:173-176.

Hokanson, S.C., A.K. Szewc-McFadden, W.F. Lamboy, and J.R. McFerson. 1998. Microsatellite (SSR) markers reveal genetic identities, genetic diversity and relationships in a Malus $\times$ domestica Borkh. core subset collection. Theoret. Appl. Genet. 97:671-683.

Isutsa, D.K., and I.A. Merwin. 2000. Malus germplasm varies in resistance or tolerance to apple replant pathogens in a mixture of New York orchard soils. HortScience 35:262-268.

Janick, J., J.N. Cummins, S.K. Brown, and M. Hemmat. 1996. Apples, p. 1-76. In: J. Janick and J. Moore (eds.). Fruit breeding. Vol II. Tree and tropical fruits. Wiley, New York.

Juniper, B.E., R. Watkins, and S.A. Harris. 1999. The origin of the apple. Acta Hort. 484:27-33.

Korban, S.S. 1986. Interspecific hybridization in Malus. HortScience 21:4148.

Kresovich, S., E.E. Dickson, and N. F. Weeden. 1988. Assessment, acquisition, and preservation of the genetic diversity of Malus spp. Genome 30 (S):406.

Lamboy, W.F., J. Yu, P.L. Forsline, and N.F. Weeden. 1996. Partitioning of allozyme diversity in wild populations of Malus sieversii Lebed. and implications for germplasm collection. J. Amer. Soc. Hort. Sci. 121:982-987.

Mehlenbacher, S.A. and A.M. Voordeckers. 1991. Relationship of flowering time, rate of seed germination, and time of leaf budbreak and usefulness in selecting for late-flowering apples. J. Amer. Soc. Hort. Sci. 116:565-568.

Momol, M.T., P.L Forsline, H.S. Aldwinckle, and W.F. Lamboy. 1999. Fire blight resistance and horticultural evaluation of wild Malus populations from Central Asia. Acta Hort. 489:229-234.

Momol, M.T., W.F. Lamboy, P.L. Forsline, and H.S. Aldwinckle. 1997. Evaluation of fire blight resistance of Malus sieversii populations from Central Asia. HortScience 32:467.

Morgan, J. and A. Richards. 1993. The book of apples. Ebury Press, London.

Noiton, D. and P. Alspach. 1996. Founding clones, inbreeding, coancestry, and status number of modern apple cultivars. J. Amer. Soc. Hort. Sci. 121:773782.

Noiton, D. and C.G.A. Shelbourne. 1992. Quantitative genetics in an apple breeding strategy. Euphytica 60:213-219.

Ponomarenko, V. 1987. History of Malus domestica Borkh., origin and evolution (in Russian with English summary). Bot. J. USSR 176:10-18.

Ponomarenko, V. 1992. Critical review of the system of the genus Malus Mill. (Rosaceae) species (in Russian with English summary). Bul. Appl. Bot. Genet. Plant Breed., Russian Acad. Agr. Sci. 146:3-11.

Stushnoff, C., O. Junttila, A. Kaurin, A.T. Ward, and N. Tyler. 1983. Screening for frost hardiness in ten week old apple seedlings. Rpt. Proc. West. Can. Soc. Hort., Banff. 39:82-85.

U.S. Dept. of Agriculture. 2000a. Agr. Res. Serv., U.S. Dept. of Agriculture, National Genetic Resources Program. Germplasm Resources Information Network (GRIN). 2000. Natl. Germplasm Resources Lab., Beltsville, Md. http://www.ars-grin.gov/ars/NoAtlantic/Geneva/kaz_trip.html

U.S. Dept. of Agriculture. 2000b. Agr. Res. Serv., U.S. Dept. of Agriculture, National Genetic Resources Program. Germplasm Resources Information Network (GRIN). 2000. Natl. Germplasm Resources Lab., Beltsville, Md. http://www.ars-grin.gov/cgi-bin/npgs/html/search.pl

Vavilov N.I. 1987. Five continents (trans. from Russian by Doris Love). Intl. Board of Plant Genet. Resources, Rome.

Way, R.D., H.S. Aldwinckle, R.C. Lamb, A. Rejman, S. Sansavini, T. Shen, R. Watkins, M.N. Westwood, and Y. Yoshida. 1992. Apples (Malus). Acta Hort. 290 (Vol. 1):1-62.

Wearing, C.H. and K. Colhoun. 1999. Bioassays for measuring the development of different apple cultivars to the development of leafrollers (Lepidoptera: Tortricidae). N.Z. J. Crop Hort. Sci. 27:91-99. 